\title{
12 Systemic consequences of intestinal inflammation
}

\author{
Konstantinos A. Papadakis and Maria T. AbreU
}

\section{Introduction}

A large number of changes, distant from the intestinal mucosa and involving many organ systems, may accompany the inflammatory process in ulcerative colitis (UC) or Crohn's disease (CD). The systemic response to inflammation includes changes in the concentration of many plasma proteins, known as the acute-phase proteins, and several neuroendocrine, metabolic, and hematopoietic alterations collectively termed the acute-phase response [1]. The acute-phase response occurs in many clinical situations characterized by tissue injury, such as trauma, ischemia, burns, infections, malignancy, and autoimmune diseases. At the molecular level these symptoms correlate with changes in the levels of proinflammatory cytokines such as tumor necrosis factor (TNF), interleukin (IL)-1, and IL-6, although other cytokines and chemokines also mediate the acute phase response. Many constitutional symptoms such as anorexia, malaise, fatigue, fever, myalgias, arthralgias, night sweats, weight loss and cachexia are directly or indirectly attributed to the effects of these proinflammatory cytokines.

During inflammation the inflammatory cytokines TNF, IL- 1 and IL- 6 are secreted in that order [2, 3]. Although many cytokine effects are predominantly paracrine and autocrine, they do mediate systemic effects [4]. For example, central infusion of TNF led to predominant anorexia whereas peripheral production of TNF produced predominant metabolic losses of protein $[5,6]$.

TNF is a $17 \mathrm{kDa}$ protein that is produced by cells of hematopoietic lineage in response to several stimuli such as bacterial pathogens and lipopolysaccharide. It is first produced as a maebrane-bound protein of $26 \mathrm{kDa}$, which is cleaved to the mature form by the TNF- $\alpha$ converting enzyme. It has several biological effects depending on the amount and the rapidity with which it is produced in response to a specific stimulus. High levels of TNF that are produced acutely lead to shock and tissue injury, vascular leakage syndrome, acute respiratory distress syndrome (ARDS), gastrointestinal necrosis, acute tubular necrosis, adrenal hemorrhage, disseminated intravascular coagulation, and fever. Chronic low-dose exposure to TNF leads to weight loss, anorexia, protein catabolism, lipid depletion, hepatosplenomegaly, insulin resistance, acute-phase protein release, and endothelial activation [6-8].

IL- 1 is a family of three proteins, IL- $1 \alpha, \mathrm{IL}-1 \beta$, and the IL-1 receptor antagonist (IL-1 ra); the latter acts as inhibitor of IL-1 signaling [9, 10]. IL-1 $\alpha$ and IL-1 $\beta$ are synthesized as precusors and are cleaved to the mature forms by the action of interleukin-1 $\beta$-converting enzyme (ICE) (caspase-1). IL-1 function as a lymphocyte-activating factor by enhancing the production of IL-2, and IL-2 receptors by T lymphocytes. It synergizes with various colony-stimulating factors to stimulate early bone marrow hematopoietic progenitor cell proliferation. IL-1 and TNF share numerous biologic activities and frequently act in synergism. IL-1 stimulates the catabolism of muscle, and in joints stimulates synovial cell proliferation, cartilage and bone resorption, and collagen deposition. The effects of IL-1 on muscles and joints contribute to the myalgias and arthralgias associated with illness. Many of the proinflammatory activities of IL-1 relate to the generation of small mediator molecules, frequently in synergy with TNF, such as platelet-activating factor and leukotrienes, prostanoids, nitric oxide, and chemokines. IL-1 has several proinflammatory activities, such as induction of fever, slow-wave sleep, anorexia, and neuropeptide release. Hypotension, myocardial suppression, septic shock, and death can all be physiologic responses to overwhelming expression of IL-1 and other proinflammatory cytokines [11]. Humans injected with IL-1 experience fever, headache, myalgias, and arthralgias, each of which is reduced by the coadministration of COX inhibitors [12].

IL- 6 is a $26-\mathrm{kDa}$ protein produced by a wide variety of cells. IL- 6 is one of the principal mediators 
of the clinical manifestations of tissue injury, including fever, cachexia, leukocytosis, thrombocytosis, increased plasma levels of acute-phase proteins, and decreased plasma levels of albumin. It is a pleiotropic cytokine with both proinflammatory and antiinflammatory properties. IL-6 also stimulates plasmacytosis and hypergammaglobulinemia and activates the hypothalamic-pituitary-adrenal axis [2]. In addition to differentiating $B$ cells, IL- 6 stimulates proliferation of thymic and peripheral T cells. Along with IL-1, IL-6 induces T cell differentiation to cytolytic $T$ cells and activates natural killer cells. These observations emphasize the importance of IL- 6 in both innate and adaptive immunity. In addition to its immunologic/inflammatory role, IL6 may play an important role in bone metabolism, spermatogenesis, epidermal proliferation, megakaryocytopoiesis, and neural cell differentiation and proliferation. The age-associated rise in IL-6 has been linked to lymphoproliferative disorders, multiple myeloma, osteoporosis, and Alzheimer's disease [13]. Recently IL-6/IL-6 receptor (IL-6R) signaling has been shown to be crucial in liver regeneration following hepatectomy $[14,15]$. The IL-6 family of cytokines, apart from IL-6 itself, comprises IL-1 I, ciliary neurotrophic factor, cardiotropin, oncostatin $\mathrm{M}$, leukemia inhibitory factor, and neurotrophin I/B cell stimulating factor 3 , which all share the common signal transducer gp130 as part of their receptors [15].

Elevated mucosal and serum levels of several proinflammatory cytokines have been observed in patients with CD and UC, including IL-1 and TNF. IL-6 serum levels have been reported to be elevated in active $\mathrm{CD}$ but not in $\mathrm{UC}$, whereas elevated circulating levels of IL-6R have been detected in active stages of both diseases [16]. Increased serum levels of IL-8 have also been reported in active UC but not in CD [17]. Approximately $90 \%$ of patients with CD have a triad of features that are persistent and progressive, namely diarrhea, abdominal pain, and weight loss [18]. As many as $40 \%$ of patients with UC may experience noticeable weight loss [19]. Cachexia, the loss of body mass that occurs in severe chronic inflammatory disease, results from decreases in skeletal muscle, fat tissue, and bone mass [20]. Cytokines such as IL-1, IL-6, TNF, and interferon gamma (IFN- $\gamma$ ) contribute to these processes [21]. Investigators have found a link between inflammatory cytokines and muscle damage. TNF- $\alpha$ and IFN- $\gamma$ are both activators of nuclear factor kappa $\mathrm{B}(\mathrm{NF}-\kappa \mathrm{B})$ in muscle. Activation of $N F-\kappa B$ results in the decreased expression of MyoD, a transcription factor that is essential for repair of damaged skeletal muscle. Thus, the net effect of TNF- $\alpha$ and IFN- $\gamma$ is defective muscle repair which may explain the cachexia that develops in patients with cancer and other high TNF- $\alpha$ states. Although cachexia is characterized by hypermetabolism, defined as an elevation in resting energy expenditure, in CD patients without malabsorption, short-term weight change is more closely related to decreased caloric intake rather than to increased resting energy expenditure. Although 'sitophobia' - in anticipation of abdominal pain - may contribute to weight loss, it usually relates to the severity of anorexia. Anorexia is one of the most common symptoms associated with acute illness, results from proinflammatory cytokine activity and has both central and peripheral elements [4]. Several cytokines affect food intake directly or indirectly with effects on other mediators such as corticotrophin-releasing hormone, serotonin, cholecystokinin, neuropeptide $Y$, insulin or leptin. A number of hypothalamic nuclei involved in eating behavior contain binding sites for cytokines [22]. In animals endotoxin increases the plasma levels of leptin and white fat leptin mRNA suggesting that leptin may be a mediator of anorexia in inflammatory states $[4,23]$. Several alterations in gastrointestinal function that indirectly affect nutritional status have been ascribed to proinflammatory cytokines, including altered gastric emptying, decreases in intestinal blood flow, changes in small bowel motility and cellular proliferation, and altered ion fluxes [4].

A significant percentage of patients with active $\mathrm{CD}$ and UC have fever, usually low-grade [19, 24]. Several cytokines, including IL- $1 \alpha$, IL- $1 \beta$, TNF, lymphotoxin $\alpha$ (LT- $\alpha$ ), IFN- $\alpha$ and IL-6, are intrinsically pyrogenic in that they produce a rapid-onset fever by acting directly on the hypothalamus without the requirement for the formation of another cytokine. Several other cytokines that use the gp130 signal transducer as part of their receptor, as mentioned earlier, may also contribute to the febrile response [25]. Pyrogenic cytokines released during the inflammatory response interact with a rich vascular network close to the cluster of neurons in the preoptic/anterior hypothalamus. These sites, called the circumventricular organs or organum vasculosum laminae terminalis (OVLT), possess little if any blood-brain barrier. It is likely that endothelial cells lining the OVLT either offer no resistance to the movement of pyrogenic cytokines into the brain or release arachidonic acid metabolites 
which then may diffuse into the preoptic/anterior hypothalamic region to induce fever. Alternatively, prostaglandin E2 $\left(\mathrm{PGE}_{2}\right)$ and other prostaglandins may be produced by the endothelial cells which, in turn, induce a neurotransmitter-like substance, such as cAMP, that acts to raise the set-point [25].

\section{Acute phase proteins}

An acute-phase protein has been defined as one whose plasma concentration increases (positive acute-phase proteins, such as C-reactive protein (CRP) and serum amino acids (SAA) or decreases (negative acute-phase proteins, such as albumin) by at least $25 \%$ during inflammation. The changes in the concentration of acute-phase proteins are due largely to changes in their production by hepatocytes [20]. Inflammatory cytokines, which operate both as a cascade and as a network in stimulating the production of acute-phase proteins, include IL-6, IL-1 $\beta$, TNF, IFN- $\gamma$, TGF- $\beta$, and IL-8 [20] (Table 1). IL-6 is a major hepatocyte stimulator and produces a variety of acute-phase proteins in the liver of experimental animals and in cultured human hepatocytes, SAA and CRP being most induced [26]. Glucocortocoids act synergistically with IL-6 in stimulating the production of acute-phase proteins. Synthesis of acute-phase proteins in IL-6 knockout mice is greatly impaired in response to non-specific irritants, such as turpentine, but is normal when bacterial lipopolysaccharide is the inflammatory stimulus [27]. Inactivation of gp130 in adult mice decreases the ability of these mice to synthesize acute-phase response proteins similarly to the IL-6 knockout mice [28]. The acute-phase proteins include several components of the complement system, which are involved in the accumulation of phagocytes at an inflammatory site and the killing of microbial pathogens. CRP binds various pathogens and materials from damaged cells, promotes opsonization of these materials, and activates the complement system. Recently it has been shown that CRP enhanced opsonization and phagocytosis of apoptotic cells by macrophages associated with the expression of the anti-inflammatory cytokine TGF- $\beta$. These observations demonstrate that CRP and the classical complement components act in concert to promote non-inflammatory clearance of apoptotic cells [29]. In this context, production of acute-phase proteins by proinflammatory cytokines can be viewed as a protective host defense mechanism that limits tissue injury [2]. How- ever, acute-phase protein production is not uniformly beneficial. For example, secondary amyloidosis has long been recognized as a deleterious consequence of elevated SAA concentrations in some patients with chronic inflammatory conditions, including IBD [30]. Several acute-phase proteins have been measured in IBD, including CRP, oromucoid ( $\alpha_{1}$-acid glycoprotein), serum and fecal $\alpha_{1}$-antitrypsin, $\beta_{2}$-microglobulin, phospholipase A2, as well as the erythrocyte sedimentation rate (ESR), and have been shown to correlate with disease activity [16].

The systemic effects of several proinflammatory cytokines have been substantiated by inhibiting their action in several human diseases. For example, Castleman's disease, an atypical lymphoproliferative disorder, is characterized by dysregulated overproduction of IL-6. Patients with this disease frequently have systemic manifestations such as fever, anemia, leukocytosis, thrombocytosis, hypergammaglobulinemia, hypoalbuminemia, and an increase in acute-phase proteins. Administration of a humanized anti-IL-6R antibody in patients with Castleman's disease led to immediate disappearance of fever and fatigue and gradual improvement of anemia, as well as serum levels of CRP, fibrinogen, and albumin, thus confirming the role of IL-6 in the systemic manifestations of the disease. Similarly patients with lymphoma who experience fever, weight loss, and night sweats (B symptoms) exhibit significantly higher levels of serum IL-6 levels compared to patients without B symptoms [31]. Anti-TNF treatment in CD and rheumatoid arthritis has been associated with a decrease in the levels of CRP and IL-6 respectively.

\section{Table 1. Relationship of cytokines to systemic manifestations}

\begin{tabular}{ll}
$\begin{array}{l}\text { Inflammatory } \\
\text { mediator }\end{array}$ & $\begin{array}{l}\text { Systemic } \\
\text { manifestations }\end{array}$ \\
\hline TNF & $\begin{array}{l}\text { Fever, cachexia, anorexia, protein catabolism, } \\
\text { insulin resistance, activation of HPA axis }\end{array}$ \\
IL-1 & $\begin{array}{l}\text { Fever, myalgias, arthralgias, bone resorption, } \\
\text { anorexia, induction of acute-phase proteins, } \\
\text { activation of HPA axis }\end{array}$ \\
IL-6 & $\begin{array}{l}\text { Fever, fatigue, leukocytosis, thrombocytosis, } \\
\text { induction of acute-phase proteins, activation } \\
\text { of HPA axis }\end{array}$ \\
\hline
\end{tabular}

HPA = hypothalamic-pituitary-adrenal axis 


\section{Hematologic consequences of intestinal inflammation}

\section{Anemia}

Anemia in patients with inflammatory bowel disease (IBD) is multifactorial and can contribute to the fatigue and poor quality of life experienced in this patient group [32, 33] (Table 2). Between one-third and one-half of patients with IBD are anemic [34-36] and the anemia may occasionally predate the development of gastrointestinal symptoms, especially in children [37-39]. Studies performed in CD patients with anemia reveal that correction of the underlying anemia improves quality-of-life scores, especially the feeling of well-being, mood, physical ability, and ability to perform social activities, supporting the idea that anemia is an important cause of constitutional symptoms [33]. This section will focus on the effect of chronic intestinal inflammation on red blood cell homeostasis and treatment of the common causes of anemia.

Intestinal ulceration, whether related to UC or CD is associated with increased intestinal blood loss, both microscopic and macroscopic, and iron deficiency anemia [35]. Iron-deficiency anemia can be assessed by measuring iron and total iron binding capacity (TIBC) levels which should reflect low iron saturation, $<15 \%$. Ferritin levels may be falsely elevated because of inflammation but low levels $(<5$ $\mu \mathrm{g} / \mathrm{L}$ ) are indicative of iron deficiency [40]. Poor iron absorption in the proximal gastrointestinal tract can contribute to the anemia of patients with $C D$ and rapid intestinal transit in both $C D$ and $U C$ can impair oral iron replacement therapy. Because oral iron supplementation is often poorly tolerated and poorly absorbed, patients may require administration of parenteral iron. In an open-label study performed in patients with UC and anemia, defined as hemoglobin $<10.5 \mathrm{~g} / \mathrm{dl}$, investigators administered iron saccharate over an 8-week period [41]. Mean hemoglobin increased by $3.6 \mathrm{~g} / \mathrm{dl}$. Only four patients out of 22 did not respond to intravenous iron. This latter group was given erythropoietin and achieved a mean hemoglobin increase of $3.3 \mathrm{~g} / \mathrm{dl}$. Similar results have been observed in patients with CD. Specifically, patients with CD and anemia who fail oral iron replacement, or are intolerant of oral iron, who are then given intravenous iron have a $75 \%$ response rate with mean hemoglobin increases of 3.3 $\mathrm{g} / \mathrm{dl}$ [33]. Intravenous iron is associated with a low $(<1 \%)$ but significant risk of anaphylactoid reaction which manifests during the first few minutes of an infusion and resembles a type I (IgE-mediated) allergic reaction $[42,43]$. More commonly up to $30 \%$ of patients given iron dextran develop arthralgias and fever within $24-48 \mathrm{~h}$ of initiation of intravenous iron therapy.

Ileal disease and resections in patients with $C D$ result in impaired vitamin $B_{12}$ absorption leading to a megaloblastic anemia. Indeed, up to three-fifths of patients with ileal $C D$ who have never had an intestinal resection have evidence of vitamin $B_{12}$ deficiency and megaloblastosis [44, 45]. As little as $30 \mathrm{~cm}$ of terminal ileum resected can lead to vitamin $B_{12}$ malabsorption, but in general greater than $60 \mathrm{~cm}$ of terminal ileum must be resected for vitamin $B_{12}$ malabsorption $[46,47]$. These patients require monthly injections of vitamin $B_{12}$ (cyanocobalamin) $(1000 \mu \mathrm{g})$ or weekly nasal delivery of topical $B_{12}$ once stores have been replenished [48]. Rarely, patients with CD and short bowel who are dependent on total parenteral nutrition (TPN) may develop anemia and pancytopenia as a result of copper deficiency [49].

The anemia experienced by patients with IBD is generally mixed and may have features of anemia of chronic disease. Anemia of chronic disease can be attributed to the increased production of the cytokines that contribute to the underlying IBD including TNF- $\alpha, 1 \mathrm{~L}-1$, and the interferons $[50,51]$. These cytokines have the effect of shortening red cell survival, blunting the erythropoietin response to anemia, impairing erythroid colony formation in response to erythropoietin, and abnormal mobilization of reticuloendothelial iron stores. Not surprisingly, the degree of anemia in patients with IBD correlates with underlying disease activity as well as systemic levels of IL-1 $\beta$ [52]. In addition to irondeficiency anemia from increased blood loss, patients with IBD have inappropriately low levels of erythropoietin for their degree of anemia and therefore cannot utilize iron appropriately [50, 52]. Erythropoietin is a renally produced hormone that regulates red blood cell mass by preventing apoptosis of erythroid precursors [53]. The reason for low erythropoietin levels in patients with IBD may be elevated systemic inflammatory cy tokines, especially TNF- $\alpha$, IL-1, IL-6 and the interferons which have been shown to decrease mRNA expression of erythropoietin [54-56]. In addition to causing lower than expected levels of erythropoietin, systemic inflammation leads to relative hyporesponsiveness to erythropoietin $[57,58]$. A study performed in UC and $C D$ patients failing oral iron therapy has shown 
that supplemental erythropoietin (150 U per kilogram of body weight twice per week) in combination with oral iron replacement $(100 \mathrm{mg} /$ day) resulted in an average hemoglobin increase of $1.7 \mathrm{~g} / \mathrm{dl}$ over a 12 week period whereas the placebo-controlled, irononly group experienced a decline in hemoglobin levels $(-0.9 \mathrm{~g} / \mathrm{dl})$ [52]. Another study performed in patients with $C D$ and anemia has shown that intravenous iron alone, or in combination with erythropoietin, is effective at increasing hemoglobin levels [33]. Patients receiving erythropoietin had greater increases in hemoglobin levels than the placebo group $(4.9 \mathrm{~g} / \mathrm{dl}$ compared with $3.3 \mathrm{~g} / \mathrm{d} 1)$. Importantly, patients whose anemia responded to therapy had an improved quality of life, suggesting that anemia does contribute to the constitutional symptoms experienced by these patients. Thus in patients with IBD and anemia who have not responded to oral iron replacement, iron levels should be evaluated. Erythropoietin is not effective in patients whose iron stores are not replete, and is the most common cause of erythropoietin resistance [59]. If iron stores are normal, patients should be treated empirically with weekly erythropoietin. A response to oral iron with or without supplemental erythropoietin is generally obtained within 8 weeks of therapy. If iron stores are reduced, intravenous iron can be used alone or in combination with erythropoietin to achieve a clinical effect.

In addition to these physiologic causes of anemia, the treatment of IBD may also result in anemia. Antimetabolites such as azathioprine (AZA) and 6mercaptopurine (6-MP) are purine antagonists and are thought to exert their beneficial effects by interfering with DNA synthesis. As a result, these drugs can cause a megaloblastic anemia that is generally dose-related [60]. Both can cause dose-dependent bone marrow suppression by inhibiting DNA and RNA synthesis. Thiopurine methyltransferase (TPMT) converts 6-MP to 6-methylmercaptopurine. TPMT is inherited in an autosomal co-dominant fashion such that patients who are heterozygous (14\% of Caucasians) or homozygous ( $1 \%$ of Caucasians) for a mutant TPMT gene have diminished or absent ability to metabolize azathioprine or 6mercaptopurine and are therefore at increased risk for developing hematologic toxicity [61-63]. In addition to an inherited inability to metabolize 6-MP/ AZA, certain mesalamine-containing compounds have been described to inhibit the TPMT enzyme, leading to bone marrow suppression [64-66]. For this reason, patients who are initiating 6-MP/AZA therapy, or who are on a stable dose but have a recent addition of a 5-ASA product, should be followed for the development of hematologic toxicity.

Sulfa and methotrexate (MTX) both interfere with folate metabolism which is required for nucleotide synthesis. Folate supplementation is required in patients taking either sulfasalazine or MTX. MTX acts by inhibiting dihydrofolate reductase. 5-Formal tetrahydrofolate (calcium leucovorin, citrovorum factor or folinic acid) administered $24 \mathrm{~h}$ after the administration of MTX can rescue normal cells from the effects of MTX by providing a reduced form of folic acid to the cells. Folate deficiency has been detected in patients receiving sulfasalazine for IBD and may be due to impaired absorption of folate [67]. Red cell folate levels correlate inversely with the dose of sulfasalazine [68]. Patients who are slow acetylators are also at increased risk for sulfasalazineinduced anemia [69]. In addition to the antimetabolite effect of drugs for IBD, mesalamine and sulfasalazine have been associated with rare cases of aplastic anemia, thrombocytopenia or neutropenia [70-73].

Perhaps the least common reason for anemia in a patient with IBD is hemolytic anemia [74-76]. Hemolytic anemia develops in an animal model of UC in which animals are genetically unable to produce IL-2 (IL-2 $\left.{ }^{-/}\right)$. Whereas the colitis in these animals is mediated by $T$ cells, $B$ cells are required for the anemia [77]. Although there are many case reports in the literature of UC associated with hemolytic anemia, it is not clear that this complication is more common in patients with IBD than in the general population $[74,78]$. In the largest series of patients reported from the Mount Sinai School of Medicine only eight patients out of 1150 hospitalized patients with UC $(0.7 \%)$ were identified with autoimmune hemolytic anemia [74]. The highest incidence of hemolytic anemia was found in a prospective study performed in 302 Greek patients with UC in which $1.7 \%$ developed autoimmune hemolytic anemia [79]. Some studies have found a correlation of the hemolysis with disease activity [79] but others have not [74]. The reasons for hemolytic anemia include idiopathic immune-mediated destruction or drugs, especially sulfasalazine [80-82]. Mononuclear cells extracted from the colon of a patient with severe hemolytic anemia and UC, but not peripheral blood cells, were able to transfer IgG with anti-red cell activity, suggesting that in certain cases the colon is the source of hemolysis-inducing antibodies [83]. Characteristics of hemolysis including high lactate 
dehydrogenase (LDH) and low haptoglobin levels should prompt a Coombs's test for the presence of anti-red blood cell (RBC) antibodies. The hemolysis generally responds to steroids but may require colectomy or splenectomy in patients who fail medical therapy [74, 79, 84].

Hemolytic anemia secondary to sulfasalazine can occur as a result of immune-mediated hemolysis associated with Coombs' positivity, or may be due to glucose-6-phosphate dehydrogenase deficiency $[80$, $81,85]$. Patients who develop Coombs' positive hemolytic anemia secondary to sulfasalazine may have been taking sulfasalazine for several years prior to the development of this type of anemia [80]. In addition to Coombs testing, agglutination studies may be done wherein sulfasalazine can be added to the patient's serum in the presence of normal erythrocytes and may demonstrate abnormal agglutination.

\section{Disorders of coagulation}

An estimated one in 1000 people in the general population experience a thrombotic episode [86] compared with approximately $1-7 \%$ of patients with IBD [87-91]; thus hypercoagulability is an important systemic consequence of IBD (Fig. 1). In addition to deep venous thromboses or life-threatening pulmonary emboli, other manifestations of hypercoagulability in patients with IBD include cerebral venous thromboses [92-98], portal vein thromboses $[99,100]$, hepatic vein thromboses (Budd-Chiari) [101-104] and arterial thromboses [105]. The reasons for hypercoagulability include inherited disorders of coagulation and acquired disorders of coagulation often due to inflammation-associated changes in hemostatic factors. Most thrombotic events are coincident with flares of IBD [87, 89]. In a study of 52 patients with IBD who experienced thromboembolic events, $45 \%$ of patients with UC and $89 \%$ of patients with $C D$ had active disease at the time of the event [90].

\section{Table 2. Evaluation of anemia in patients with inflammatory bowel disease}

\begin{tabular}{lll}
$\begin{array}{l}\text { Cause of } \\
\text { anemia }\end{array}$ & $\begin{array}{l}\text { Characteristics } \\
\text { of anemia }\end{array}$ & Disease prevalence \\
\hline $\begin{array}{l}\text { Increased intestinal } \\
\text { blood loss }\end{array}$ & $\begin{array}{c}\text { Iron deficiency/ } \\
\text { microcytic }\end{array}$ & $\begin{array}{c}\text { Ulcerative colitis }> \\
\text { Crohn's disease }\end{array}$
\end{tabular}

Diminished iron absorption

Drug-induced

chronic disease

Normocytic or

microcytic if mixed

Crohn's disease $>$ ulcerative colitis

Crohn's disease >
ulcerative colitis
Both

\section{Vitamin $\mathrm{B}_{12}$}

\section{Anti-RBC} deficiency

antibodies
Megaloblastic

Megablastic

Hemolytic anemia

\author{
Crohn's disease \\ (ileal disease or \\ ileal resection) \\ Ulcerative colitis > \\ Crohn's disease
}

*Parenteral iron dextran replacement is based on the following formula: $0.0476 \times($ normal hemoglobin - observed hemoglobin in $\mathrm{g} / \mathrm{dl})( \pm) 1 \mathrm{ml} / 5$ $\mathrm{kg}$ body weight (up to maximum of $14 \mathrm{ml}$ ) which accounts for storage iron = total dosage of iron-dextran in $\mathrm{ml}$.

Vitamin $B_{12}$ levels

Monthly IM B12 injections $1000 \mu \mathrm{g}$ dose
Corticosteroids, usually self-limited
Coombs test positive
Treatment

$\begin{array}{lc}\text { Serum } \mathrm{Fe}, \mathrm{TIBC} \text { ratio }<15 \% ; & \text { Oral iron replacement } \\ \text { ferritin }<5 \mu \mathrm{g} / \mathrm{L} \text { (may be } & \text { (ferrous sulfate } 300 \mathrm{mg} \\ \text { confounded by acute } & \text { t.i.d.); if no response within } \\ \text { inflammation) } & 4 \text { weeks, parenteral iron } \\ & \text { replacement }\end{array}$

Serum Fe, TIBC ratio $<15 \%$

Normal iron stores, $B_{12}$ and folate; drug withdrawal or dose adjustment improves anemia within 4 weeks

Serum Fe, TIBC ratio $>15 \%$ (serum erythropoietin levels are not useful)

Parenteral iron replacement ${ }^{*}$

Reduce dose of antimetabolite; supplement with folate (sulfasalazine or MTX); leucovorin (MTX)

Supplement with recombinant erythropoietin $(150 \mathrm{U} / \mathrm{kg}$ t.i.w. subq for up to 12 weeks or $10000 \mathrm{U}$ subq q week) 
Active IBD is associated with changes in hemostatic factors which may lead to hypercoagulability. Increases in coagulation factors are known risk factors for the development of thromboembolic disease [106]. The most common hemostatic abnormality identified in patients with IBD is thrombocytosis, which correlates with underlying bowel disease activity [107] (Table 3). In a study of 92 thromboembolic events occurring in $7199(1.3 \%)$ patients with IBD, $60 \%$ of patients had thrombocytosis and $73 \%$ had elevated ESR values, suggesting active IBD [89]. Patients with IBD have increased levels of thrombin generation (prothrombin fragment $1+2$ and thrombin-antithrombin III complex) compared with control populations, and these levels correlate with disease activity [107-110]. Fibrinogen, factor V and factor VIII are also commonly elevated in patients with IBD whereas the anticoagulant factors antithrombin III, and proteins $\mathrm{S}$ and $\mathrm{C}$, are decreased, which may contribute to the propensity for thrombosis [89, 107, 110-119]. Other plateletrelated abnormalities identified in patients with IBD are increased spontaneous and induced platelet aggregation which correlated with a history of thromboembolism in seven of eight patients [107, 120]. Surgical resections in patients with CD result in significant decreases in platelet counts, fibrinogen levels and spontaneous platelet aggregation supporting the concept that the underlying bowel disease contributes to the hypercoagulable state [121]. Increased platelet mass in IBD is due to systemic increases in thrombopoietin and IL-6 [122]. Specifically, patients with active IBD have significantly increased levels of thrombopoietin compared with patients in remission and this increase in thrombopoietin is associated with increased platelet counts. Increased megakaryocyte maturation occurs in response to endogenous production of IL-11 and increases with IL-11 therapy for IBD [123]. Acute inflammation can also result in increased hepatic production of fibrinogen and increased platelet aggregation, which is another risk factor in thrombosis. A study of thrombotic risk factors in IBD found that patients with IBD had increased plasma factor VII coagulant activity (a marker of thrombin generation), lipoprotein (a) and fibrinogen concentrations compared with a normal population [124].

With respect to acquired disorders of coagulation, anticardiolipin antibodies or the lupus anticoagulant are associated with an increased risk of thromboembolic events, and have been found with increased frequency in patients with IBD [107, 118, 125].
Studies examining the prevalence of anticardiolipin antibodies in patients with IBD found that both CD and UC patients had increased antibody titers compared to a control group, but the presence of anticardiolipin antibodies was not associated with a higher risk of thromboembolic events in these patients [87, 126]. Others, however, have described the presence of a lupus anticoagulant in the setting of severe thrombotic events such as dural sinus thrombosis or hepatic vein thrombosis in patients with IBD $[94,104,127]$. Based on these studies, a screen for a lupus anticoagulant should be part of the evaluation of a patient with IBD and a recognized thrombotic event, but has little predictive value in a patient without demonstrated hypercoagulability.

Patients with hypercoagulability and IBD may have inherited disorders of coagulation. In combination with inflammation-associated changes in hemostasis these inherited disorders may become manifest [128]. Activated protein $\mathrm{C}$ resistance from a mutation in the prothrombin gene (factor V Leiden) is the most common inherited disorder leading to thrombosis, and accounts for $30-40 \%$ of episodes of idiopathic venous thrombosis [128-130]. Other inherited causes of hypercoagulability include hyperhomocysteinemia and mutations in the prothrombin gene [131]. Since the description of the relatively common factor $V$ Leiden mutation as an inherited cause of thrombophilia, several groups have investigated the frequency of this mutation in IBD patients with and without a history of thromboembolism. A study evaluating the prevalence of factor $V$ Leiden, methylene tetrahydrofolate reductase (resulting in hyperhomocysteinemia) and prothrombin gene mutations in IBD patients without thrombosis compared with an age-matched control group found no increase in these inherited disorders [132]. Several studies examining the prevalence of activated protein $C$ resistance or factor $V$ Leiden mutations in adults or children with IBD and without a history of thrombosis have not found an increased prevalence of these mutations compared with healthy controls $[119,133,134]$. A large Greek series identified factor $V$ Leiden mutations in $8.3 \%$ of IBD patients, which was not significantly different when compared with a healthy control group with a $4.9 \%$ mutation rate [111]. Two studies found a slightly increased allelic frequency of factor $\mathrm{V}$ Leiden mutations in UC [135] or CD patients [136], but the sample sizes were limited. Although the prevalence of factor $\mathrm{V}$ Leiden mutations or resistance to activated protein $\mathrm{C}$ does not appear to be increased in an unselected population of IBD patients, the frequency of this 
mutation is increased in those IBD patients with a history of thromboembolic events. An Austrian study evaluated the presence of resistance to activated protein C in patients with IBD compared with healthy controls. In IBD patients without a history of thromboembolism, the frequency of activated protein $\mathrm{C}$ resistance was similar to that of healthy controls $(7 \%$ versus 5.9\%) [137]. By contrast, 31.3\% of IBD patients with a history of thromboembolism had activated protein $C$ resistance, suggesting that patients with thromboembolism and IBD are just as likely to have activated protein $\mathrm{C}$ resistance as patients with thromboembolism in the general population [129]. Similar results were observed in an American study that found four of 11 IBD patients $(36 \%)$ with thrombosis and two of 51 IBD controls $\left(4^{\prime \prime} \%\right)$ were heterozygotes for the factor $V$ Leiden mutation [138]. In a group of 20 patients with IBD complicated by thrombosis, a screen for the most common inherited and acquired disorders of coagulation including protein $\mathrm{S}$, protein $\mathrm{C}$ levels, and antithrombin III levels, antiphospholipid antibodies, and activated protein $C$ resistance were negative, with only one patient found to be heterozygous for factor $V$ Leiden mutation [90]. In patients with IBD there is an increased prevalence of hyperhomocysteinemia, a risk factor for thrombophilia, which can be corrected by the administration of folate, cobalamin and pyridoxine [139]. Recent data also suggest that patients with IBD have increased prevalence of the C677T variant of the methylenetetrahydrofolate reductase gene $(17 \%$ versus $7.3 \%$ in healthy controls) which is associated with thromboembolic disease [140]. In a retrospective study of 231 patients with IBD, hyperhomocysteinemia was more prevalent in patients than in healthy controls, but was not higher in IBD patients with a history of thromboembolic disease [141]. These studies suggest that the majority of patients with thromboembolic events and IBD have the same risk as the rest of the population for inherited disorders of coagulation, but the majority will have no identifiable risk factor except active inflammation. Although the risk of inherited disorders predisposing to thrombophilia is not increased in IBD patients, there is an epidemiologic study suggesting that hemophilia and Von Willebrand's disease are under-represented in the IBD population [142]. As the molecular mechanisms regulating disorders of coagulation are elucidated, additional patients with IBD and hypercoagulability will be recognized to have an inherited disorder of coagulation.
Management of thromboses in patients with IBD requires a multi-faceted approach (see Fig. 1). Even in patients with active IBD, a search for an underlying disorder of coagulation is required. If active IBD is the only identifiable risk factor for the thrombosis, and it is a single thrombotic event, short-term anticoagulation combined with treatment of the underlying IBD is appropriate [143]. Heparin therapy can generally be given safely, and has a small therapeutic benefit in patients with UC [144]. Thrombolytic therapy may be given cautiously in IBD patients with extensive thromboses or if the condition is life-threatening [145, 146]. In patients with recurrent thrombotic episodes or life-threatening thromboses, long-term anticoagulation is required. This may be difficult in the setting of active IBD because of associated intestinal bleeding.

In addition to hypercoagulability due to inherited genetic mutations in coagulation factors or inflammation, there are multiple case reports of disseminated intravascular coagulation in patients with $\mathrm{UC}$ generally associated with a flare of the UC [148-150]. Thrombocytopenia may also complicate IBD, and may be immune-mediated $[151,152]$ or associated with drug-induced bone marrow suppression as described above. Cases of sulfasalazine-induced and mesalamine-induced immune-mediated thrombocytopenia have been reported [153].

\section{Leukocytosis}

As with inflammation of any type, leukocytosis is often present in patients with IBD [122]. Elevated leukocyte counts prior to surgical resection for $C D$ are associated with an increased risk of recurrence [154]. White blood cell counts above 18000 or the presence of an elevated band count, should prompt an investigation for a septic process. Neutrophil and monocyte maturation and release from the bone marrow is regulated by granulocyte colony-stimulating factor (GCSF) and monocyte colony-stimulating factor (MCSF), respectively. These factors are derived from bone marrow stromal cells and monocytes which are activated by IL-1, TNF- $\alpha$ and LPS to release these trophic factors. In addition, GM-CSF is derived from activated $\mathrm{T}$ lymphocytes and IL-1/ TNF- $\alpha$-activated stromal cells and monocytes. In patients with active IBD, leukocytosis correlates with serum concentrations of IL-6 and thrombocytosis [122]. The presence of leukocytosis in patients with active IBD is thus related to increased circulating levels of proinflammatory cytokines or a septic 


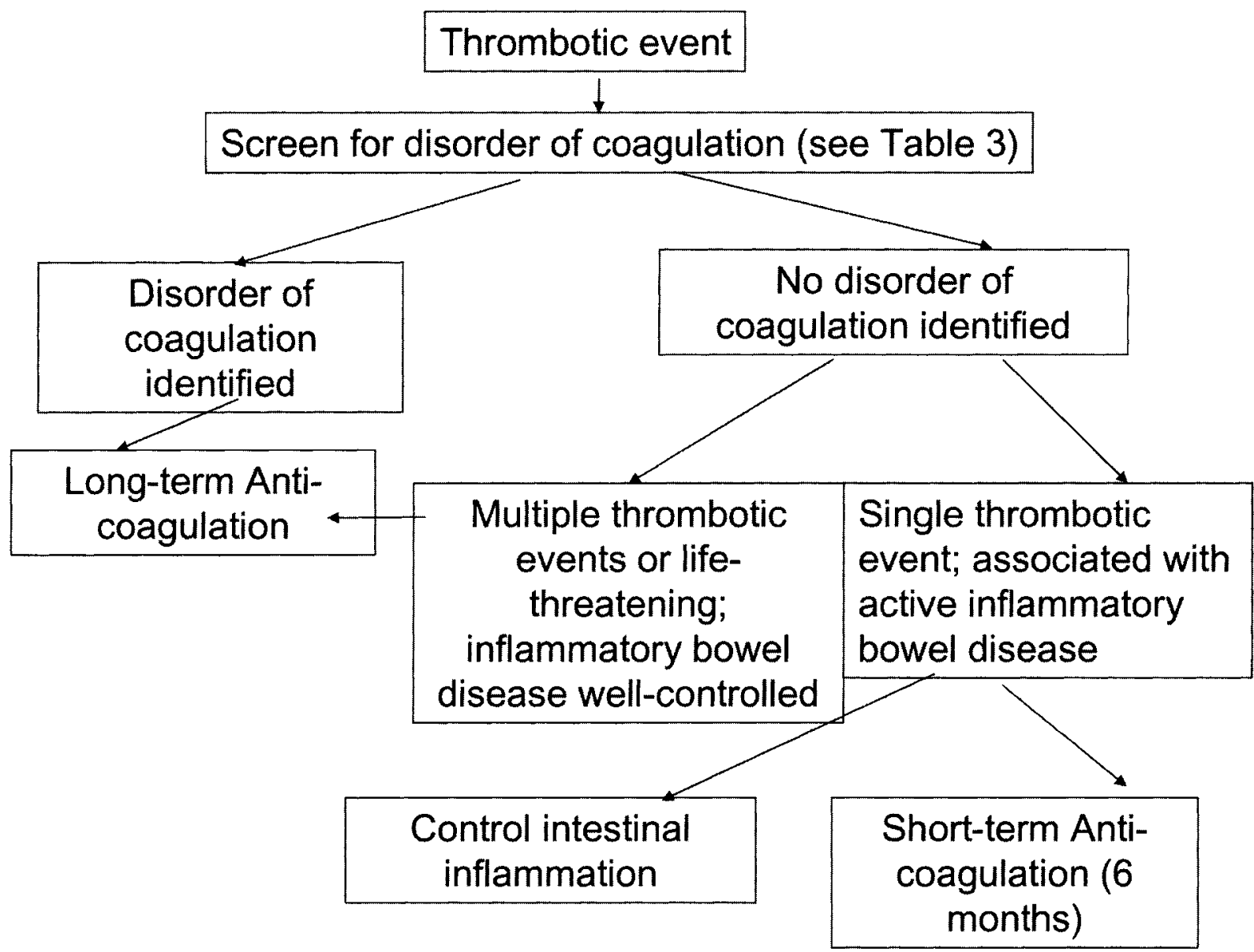

Figure 1. Evaluation of the IBD patient with a thrombotic event.

Table 3. Causes of hypercoagulability in patients with inflammatory bowel disease $[128,147]$

\section{Inherited causes of hypercoagulability}

Activated protein $C$ resistance ( $\operatorname{Arg} 506$ changed to GIn in factor $V$ ) (factor V Leiden mutation)

Prothrombin G20210A polymorphism (results in increased levels of prothrombin)

Methylene tetrahydrofolate reductase mutations (hyperhomocysteinemia)

Deficiency or mutations in protein $\mathrm{C}$

Deficiency or mutations in protein $\mathrm{S}$

Antithrombin III deficiency

\section{Acquired causes of hypercoagulability}

Thrombocytosis (active inflammation)

Increased platelet aggregation

Elevated factor VIII plasma levels

Elevated fibrinogen levels

Anticardiolipin antibodies

Deficiency in protein $\mathrm{S}$

Secondary hyperhomocysteinemia (due to folate, pyridoxine or cobalamin deficiency) 
complication such as a microperforation, frank perforation or abscess. Corticosteroids also lead to leukocytosis secondary to down-regulation of intercellular adhesion molecule expression and granulocyte demargination.

\section{Hematologic malignancies}

In spite of multiple case reports of leukemias or lymphomas associated with IBD, it remains controversial whether patients with IBD are at increased risk for the development of hematologic malignancies either as a result of chronic inflammatory disease or its treatment [155-157]. Other chronic inflammatory disorders such as rheumatoid arthritis do pose an increased risk of hematologic malignancies [158]. Based on several case series and population-based studies, it seems that patients with $C D$ are at a slightly increased risk for the development of nonHodgkin's lymphomas than the average population search. A recent study based on Olmstead County, Minnesota, records found a standardized incidence ratio of lymphomas of 2.4 ( $95 \%$ confidence intervals $0.1-13$ ) in patients with CD and no cases of lymphomas occurred in patients with UC [155]. Only three patients out of 61 who developed lymphomas were receiving purine analogs. Few patients with IBD in this study were on immunomodulator therapy thus this may represent the true incidence of lymphomas in IBD patients in the absence of immunosuppressive therapy. There was no increased risk of leukemia in these patients. In another large series of IBD patients, five lymphomas occurred among 1156 patients $(0.43 \%)$ with UC and four lymphomas among 1480 patients $(0.27 \%)$ with CD and the risk of lymphomas correlated with disease duration in patients with CD [159]. A recent population-based study performed in Florence, Italy, reported a ninefold increased incidence of Hodgkin's lymphoma in patients with UC compared with the general population [160]. The same study found a reduced risk (standardized incidence ratio 0.6 ) of respiratory tract cancers in patients with UC and increased risk in patients with CD. Severity of the IBD has not been established as an independent risk factor in the development of lymphomas.

Immunosuppressive therapy has been implicated as a risk factor in the development of hematologic malignancies, but a causal role of immunosuppressive therapy in the development of lymphomas associated with IBD has not been established $[161,162]$. To date there have been three published cases of brain lymphomas (one each from three large series) in patients with IBD on long-term AZP or 6MP in a total of 1701 patients $[156,161,163]$. Although the overall risk of brain lymphomas is low in patients with IBD treated with purine antimetabolites, immunosuppression is clearly a risk factor for this otherwise rare malignancy [164]. In a series of 550 patients with IBD on long-term 6-MP therapy, two patients developed non-Hodgkin's lymphoma, one leukemia and one brain lymphoma [161]. The overall rate of these malignancies was not higher than in the general population. Two other large series of 755 and 396 patients found no excess in the risk of any hematologic malignancies in IBD patients treated with AZP or 6-MP [156, 163]. A decision analysis comparing the efficacy of AZP at maintaining remission in IBD compared with the risk of non-Hodgkin's lymphoma found that AZP was favorable and resulted in improved quality of life [165]. In spite of the encouraging data in patients with IBD, children treated with 6-MP for acute lymphoblastic leukemia have an increased risk of secondary myelodysplasia or acute myeloid leukemia (5/493), and this risk is associated with low TPMT enzymatic activity and high erythrocyte 6-thioguanine nucleotides [166]. 6MP and AZP have also been associated with rare cases of acute myeloid leukemia in patients with autoimmune diseases including IBD treated for prolonged periods of time [167, 168]. In all the cases a prolonged pancytopenic phase preceded the onset of the leukemia suggesting an antecedent myelodysplastic phase.

Immunocompromised hosts, especially patients who have undergone solid organ transplantation, are at significantly increased risk for the development of B cell lymphomas related to Epstein-Barr virus (EBV) infection $[169,170]$. The risk in patients post-transplantation is thought to be high because of the use of multiple immunosuppressive drugs, as well as the long-term nature of the immunosuppression. In a series of four patients with gastrointestinal Hodgkin's lymphoma and IBD, all four lymphomas were found to be EBV-mediated with only two patients on immunomodulator therapy [171]. An additional case of an EBV-driven lymphoproliferative disorder in a CD patient on long-term AZP regressed after discontinuation of the AZP [172, 173]. Finally, one B cell lymphoma and one Hodgkin's lymphoma have been reported in patients with $\mathrm{CD}$ after receiving infliximab anti-TNF- $\alpha$ therapy [174]. These lymphomas occurred 3 weeks and 10 months after receiving infliximab. It is too soon to 
determine the relationship of anti-TNF- $\alpha$ strategies to the development of hematologic malignancies.

\section{Amyloidosis in patients with IBD}

An uncommon but morbid systemic consequence of IBD is the development of amyloidosis [30, 175-177]. Amyloidosis is a group of diseases characterized by the extracellular deposition of pathologic insoluble fibrillar proteins in organs and tissues [178, 179]. There are three principal forms of amyloidosis. Systemic AL amyloidosis is associated with blood cell dyscrasias and monoclonal gammopathies. There are multiple familial forms of amyloidosis or type ATTR amyloidosis. As with other chronic inflammatory states such as rheumatoid arthritis, IBD may rarely result in secondary systemic amyloidosis type AA [180, 181]. In general, rheumatologic diseases are more commonly associated with amyloidosis than IBD, and CD is more often complicated by amyloidosis than UC $[175,178,179,182]$. In a large series of IBD followed at the Mount Sinai Hospital, amyloidosis occurred in 15 of 1709 patients with $\mathrm{CD}(0.9 \%)$ and one of 1341 patients with $\mathrm{UC}$ $(0.07 \%)$ [30]. Amyloidosis was more often associated with $\mathrm{CD}$ of the colon than with pure small bowel disease.

The diagnosis of amyloidosis is made by appropriate pathology demonstrating Congo red-positive amyloid deposits on fat-pad biopsy, rectal biopsy or renal biopsy [178, 179]. Scintigraphy has recently been developed as a non-invasive and quantitative alternative to histology. A radioactive tracer ${ }^{123} \mathrm{I}$ serum amyloid $\mathbf{P}$ component is injected and specifically targets amyloid deposits in vivo. The technique has almost $100 \%$ sensitivity for systemic AA amyloidosis. In four patients with CD and amyloidosis, ${ }^{123} \mathrm{I}$ serum amyloid $\mathbf{P}$ nuclear medicine scanning demonstrated the increased amyloid content and correlated with disease improvement following renal transplantation [180].

In patients with $\mathrm{CD}$ and $\mathrm{AA}$ amyloidosis, proteinuria is the most common presentation $[30,175,177$, $179,180,183]$. The overall 5-year mortality for AA amyloidosis is $50 \%[178,179]$. In one series, one of four patients died prior to renal transplantation demonstrating the high morbidity and mortality from this complication [180]. Nephropathy is the most common lethal manifestation of IBD-associated amyloidosis. Nephrotic syndrome was responsible for 10 deaths out of 25 patients with IBDassociated amyloidosis in a large series [30].
Therapy for type AA amyloidosis is directed at limiting the acute-phase response generating the amyloid protein [178, 179]. Unfortunately, this type of amyloidosis is generally advanced by the time of diagnosis with extensive amyloid deposits and renal failure [175]. Only limited case report information is available on the management of IBD complicated by amyloidosis. Several cases of UC complicated by AA amyloidosis have been effectively treated with colchicine, which led to reduction in proteinuria $[182,184$ 187]. AZP and colchicine combination therapy has also been effective in improving amyloidosis-induced renal failure and controlling CD in one patient [188]. An elemental diet has been reported as effective in preventing ongoing renal damage in a $\mathrm{CD}$ patient with amyloidosis [189]. Regression of amyloid has also been reported in patients with $C D$ after bowel resection or after treatment with dimethylsulfoxide (DMSO) [190, 191]. Based on the limited data, periodic tests of renal function are warranted in patients with IBD to assess nephrotoxicity from medications, as well as the rare occurrence of amyloidosis.

\section{References}

1. Chrousos GP. The hypothalamic-pituitary-adrenal axis and immune-mediated inflammation. N Engl J Med 1995; 332: $1351-62$.

2. Papanicolaou DA, Wilder RL, Manolagas SC, Chrousos GP. The pathophysiologic roles of interleukin-6 in human disease. Ann Intern Med 1998; 128: 127-37.

3. van Deventer SJ, Buller HR, ten Cate JW, Aarden LA, Hack CE, Sturk A. Experimental endotoxemia in humans: analysis of cytokine release and coagulation, fibrinolytic, and complement pathways. Blood 1990; 76: 2520-6.

4. Kotler D. Cachexia. Annals Intern Med 2000; 133: 622-34.

5. Tracey KJ, Morgello S, Koplin B et al. Metabolic effects of cachectin/tumor necrosis factor are modified by site of production. Cachectin/tumor necrosis factor-secreting tumor in skeletal muscle induces chronic cachexia, while implantation in brain induces predominantly acute anorexia. J Clin Invest 1990; 86: 2014-24.

6. Tracey KJ, Cerami A. Tumor necrosis factor: a pleiotropic cytokine and therapeutic target. Annu Review of Med 1994; 45: 491-503.

7. Papadakis KA, Targan SR. Role of cytokines in the pathogenesis of inflammatory bowel disease. Annu Rev Med 2000; 51: 289-98.

8. Papadakis KA, Targan SR. Tumor necrosis factor: biology and therapeutic inhibitors. Gastroenterology 2000; 119 : $1148-57$.

9. O'Neill LA, Dinarello CA. The IL-1 receptor/toll-like receptor superfamily: crucial receptors for inflammation and host defense. Immunol Today 2000; 21: 206-9.

10. Howard AD, Kostura MJ, Thornberry N et al. IL-1-converting enzyme requires aspartic acid residues for processing of the IL-1 beta precursor at two distinct sites and does not cleave 31-kDa IL-1 alpha. J Immunol 1991; 147: 2964 9. 
11. Rosenwasser LJ. Biologic activities of IL-1 and its role in human disease. J Allergy Clin Immunol 1998; 102: 344-50.

12. Dinarello CA. Proinflammatory cytokines. Chest $2000 ; 118$ : 503-8.

13. Ershler WB, Keller ET. Age-associated increased interleukin-6 gene expression, late-life diseases, and frailty. Annu Rev Med 2000; 51: 245-70.

14. Cressman DE, Greenbaum LE, DeAngelis RA et al. Liver failure and defective hepatocyte regeneration in interleukin6-deficient mice. Science 1996; 274: 1379-83.

15. Streetz KL, Luedde T, Manns MP, Trautwein C. Interleukin 6 and liver regeneration. Gut 2000; 47: 309-12.

16. Nielsen $\mathrm{OH}$, Vainer B, Madsen SM, Seidelin JB, Heegaard NH. Established and emerging biological activity markers of infiammatory bowel disease. Am J Gastroenterol 2000; 95: $359-67$

17. Mahida YR, Ceska M, Effenberger F, Kurlak L, Lindley I, Hawkey CJ. Enhanced synthesis of neutrophil-activating peptide-1/interleukin-8 in active ulcerative colitis. Clin Sci 1992; 82: 273-5

18. Farmer RG, Hawk WA, Turnbull RB Jr. Clinincal patterns in Crohn's disease: a statistical study of 615 cases. Gastroenterology 1975; 68:627 35 .

19. Sparberg M. Fennessy J, Kirsner JB. Ulcerative proctitis and mild ulcerative colitis: a study of 220 patients. Medicine 1966: 45: 391412.

20. Gabay C, Kushner I. Acute-phase proteins and other systemic responses to inflammation [published erratum appears in $\mathrm{N}$ Engl J Med 1999: 340: 1376]. N Engl J Med 1999; 340:448 54 .

21. Moldawer LL, Copeland EM IIIrd. Proinflammatory cytokines, nutritional support, and the cachexia syndrome: interactions and therapeutic options. Cancer 1997: 79: 182839

22. Platat-Salaman CR. Food intake suppression by growth factors and platelet peptides by direct action in the central nervous system. Neurosci Lett 1988:94:1616.

23. Sarraf P, Frederich RC. Turner EM e't al. Multiple cytokines and acute inflammation raise mouse leptin levels: potential role in inflammatory anorexia. J Exp Med 1997; 185: 171.5.

24. Both H. Torp-Pedersen K, Kreiner S, Hendriksen C, Binder V. Clinical appearance at diagnosis of ulcerative colitis and Crohn's disease in a regional patient group. Scand $J$ Gastroenterol 1983; 18: 987 -91.

25. Dinarello CA. Cytokines as endogenous pyrogens. J Infect Dis 1999; 179 (Suppl 2): S294-304.

26. Castell JV, Gomez-Lechon MJ, David M et al. Interleukin-6 is the major regulator of acute phase protein synthesis in adult human hepatocytes. FEBS Lett $1989 ; 242$; 237-9.

27. Fattori E, Cappelletti M, Costa P et al. Defective inflammatory response in interleukin 6-deficient mice. J Exp Med 1994; 180: 1243-50.

28. Betz UAK, Bloch W, van den Broek $M$ et al. Postnatally induced inactivation of gpl 30 in mice results in neurological, cardiac, hematopoietic, immunological, hepatic, and pulmonary defects. J Exp Med 1998; 188: 1955-65.

29. Gershov D, Kim S, Brot N, Elkon K. C-reactive protein binds to apoptotic cells, protects the cells from assembly of the terminal complement components, and sustains an antiinflammatory innate immune response: implications for systemic autoimmunity. J Exp Med 2000; 192: 1353-64.

30. Greenstein AJ, Sachar DB, Panday AK et al.: Amyloidosis and inflammatory bowel disease. A 50-year experience with 25 patients. Medicine 1992; 71: 261-70.

31. Kurzrock R, Redman J, Cabanillas F, Jones D, Rothberg J, Talpaz M. Serum interleukin 6 levels are elevated in lymphoma patients and correlate with survival in advanced Hodgkin's disease and with B symptoms. Cancer Res 1993; 53: $2118-22$.
32. Gasche C. Anemia in IBD: the overlooked villain. Inflammat Bowel Dis 2000; 6: 142-50; discussion 151.

33. Gasche $\mathrm{C}$, Dejaco $\mathrm{C}$, Waldhoer T et al. Intravenous iron and erythropoietin for anemia associated with Crohn disease. A randomized, controlled trial. Ann Intern Med 1997; 126: 782-7.

34. Horina JH, Petritsch W, Schmid CR et al. Treatment of anemia in inflammatory bowel disease with recombinant human erythropoietin: results in three patients. Gastroenterology 1993: 104: 1828-31.

35. Gasche C, Reinisch W, Lochs $\mathrm{H}$ et al. Anemia in Crohn's disease. Importance of inadequate erythropoietin production and iron deficiency. Dig Dis Sci 1994; 39: 1930-4.

36. Beeken WL. Remediable defects in Crohn disease: a prospective study of 63 patients. Arch Intern Med 1975; 135: 686-90.

37. Gold Y, Reif S. [Aphthous stomatitis as a first manifestation of Crohn's disease in a 5 year-old boy]. Harefuah 1998: 135: $3646,407$.

38. Froom P, Benbassat J, Kiwelowicz A, Erel J, Davidson B, Ribak J. Significance of low hematocrit levels in asymptomatic young adults: results of 15 years follow-up. Aviat Space Environ Med 1999; 70: 9836.

39. Menachem Y, Weizman Z, Locker C. Odes S. Clinical characteristics of Crohn's disease in children and adults. Harefuah 1998; 134: 173 5, 247.

40. Smith AD, Cochran KM. Serum ferritin: it may guide the diagnosis of the anaemic patient. Scot Med J 1997;42: 182 3.

41. Gasche $C$, Dejaco C, Reinisch $W$ ef al.Sequential treatment of anemia in uleerative colitis with intravenous iron and crythropoictin. Digestion 1999; 60: 2627.

42. Macdougall IC. Strategies for iron supplementation: oral versus intravenous. Kidney Int (Suppl.) 1999; 69: S61 6.

43. Hamstra RD, Block MH, Schocket AL. Intravenous iron dextran in clinical medicine. J Am Med Assoc 1980; 243: 172631.

44. Dyer N. Dawson A: Malnutrition and malabsorption in Crohn's disease with references to the effect of surgery. Br J Surg 1973; 60: 13440.

45. Dyer NH, Child JA, Mollin DL. Dawson AM. Anaemia in Crohn's disease. Q J Med 1972; 41:419 36.

46. Thompson W. Wrathell E. The relation between ileal resection and vitamin B12 absorption. Can J Surg 1977; 20: 4614.

47. Fone D et al. $\left[^{58}\right]$ Co B- 12 absorption after gastrectomy, ileal resection and in coeliac disorders. Gut 1961;2: 218.

48. Lee $\mathrm{G}$. Pernicious anemia and other causes of vitamin $\mathrm{B} 12$ (cobalamin) deficiency. In: Lee $G$ (ed.), Wintrobe's Clinical Hematology, 10th edn. Baltimore: Lippincott, Williams \& Wilkins, 1999; 956.

49. Spiegel JE, Willenbucher RF. Rapid development of severe copper deficiency in a patient with Crohn's disease receiving parenteral nutrition. J Parent Ent Nutr 1999; 23: 169-72.

50. Means RT Jr. Erythropoietin in the treatment of anemia in chronic infectious, inflammatory, and malignant diseases. Curr Opin Hematol 1995; 2: 210-3.

51. Means RT Jr. Advances in the anemia of chronic disease. Int J Hematol 1999; 70: 7-12.

52. Schreiber S, Howaldt S, Schnoor M et al. Recombinant erythropoietin for the treatment of anemia in inflammatory bowel disease. N Engl J Med 1996; 334: 619-23.

53. Koury $\mathbf{M}$, Bondurant $\mathbf{M}$. The molecular mechanism of erythropoietin action. Eur J Biochem 1992; 210: 649-63.

54. Jelkmann WE, Fandrey J, Frede S, Pagel H: Inhibition of erythropoietin production by cytokines. Implications for the anemia involved in inflammatory states. Ann NY Acad Sci 1994; 718: 300-9; discussion 309-11. 
55. Jelkmann W. Proinflammatory cytokines lowering erythropoietin production. J Interferon Cytokine Res 1998; 18: 555-9.

56. Faquin WC, Schneider TJ, Goldberg MA. Effect of inflammatory cytokines on hypoxia-induced erythropoietin production. Blood 1992; 79: 1987-94.

57. Gunnell J, Yeun JY, Depner TA, Kaysen GA. Acute-phase response predicts erythropoietin resistance in hemodialysis and peritoneal dialysis patients. Am $\mathbf{J}$ Kidney Dis 1999; 33: 63-72.

58. Nordstrom D, Lindroth Y, Marsal L et al. Availability of iron and degree of inflammation modifies the response to recombinant human erythropoietin when treating anemia of chronic disease in patients with rheumatoid arthritis. Rheumatol Int 1997; 17: 67-73.

59. Tarng DC, Huang TP, Chen TW, Yang WC. Erythropoietin hyporesponsiveness: from iron deficiency to iron overload. Kidney Int (Suppl.) 1999; 69: S107-18.

60. Lennard L, Murphy M, Maddocks J: Severe megaloblastic anaemia associated with abnormal azathioprine metabolism. Br J Clin Pharmacol 1984; 17: 171.

61. Weinshilboum RM, Sladek SL. Mercaptopurine pharmacogenetics: monogenic inheritance of erythrocyte thiopurine methyltransferase activity. Am J Hum Genet 1980; 32; $651-$ 62.

62. Schutz E, Gummert J, Armstrong VW, Mohr FW, Oellerich M. Azathioprine pharmacogenetics: the relationship between 6-thioguanine nucleotides and thiopurine methyltransferase in patients after heart and kidney transplantation. Eur J Clin Chem Clin Biochem 1996; 34 : 199-205.

63. Lennard L, Van Loon JA, Lilleyman JS, Weinshilboum RM. Thiopurine pharmacogenetics in leukemia: correlation of erythrocyte thiopurine methyltransferase activity and 6thioguanine nucleotide concentrations. Clin Pharmacol Ther $1987 ; 41: 18-25$

64. Lowry PW, Szumlanski CL, Weinshilboum RM, Sandborn WJ. Balsalazide and azathiprine or 6-mercaptopurine: evidence for a potentially serious drug interaction [Letter; comment]. Gastroenterology 1999; 116: 1505-6.

65. Lewis LD, Benin A, Szumlanski CL et al. Olsalazine and 6mercaptopurine-related bone marrow suppression: a possible drug-drug interaction [Published erratum appears in Clin Pharmacol Ther 2000; 67:431]. Clin Pharmacol Ther 1997; 62: 464-75.

66. Szumlanski CL, Weinshilboum RM. Sulphasalazine inhibition of thiopurine methyltransferase: possible mechanism for interaction with 6-mercaptopurine and azathioprine. $\mathrm{Br}$ J Clin Pharmacol 1995; 39: 456-9.

67. Swinson CM, Perry J, Lumb M, Levi AJ. Role of sulphasalazine in the aetiology of folate deficiency in ulcerative colitis. Gut 1981; 22: 456-61.

68. Longstreth $G$, Green R. Folate status in patients receiving maintenance doses of sulfasalazine. Arch Intern Med 1983; 143: 902.

69. Das KM, Eastwood MA, McManus JP, Sircus W. Adverse reactions during salicylazosulfapyridine therapy and the relation with drug metabolism and acetylator phenotype. $\mathrm{N}$ Engl J Med 1973; 289; 491-5.

70. Abboudi ZH, Marsh JC, Smith-Laing G, Gordon-Smith EC. Fatal aplastic anaemia after mesalazine [Letter]. Lancet 1994; 343: 542 .

71. Dunn AM, Kerr GD. Pure red cell aplasia associated with sulphasalazine [Letter]. Lancet $1981 ; 2: 1288$.

72. Daneshmend T. Mesalazine-associated thrombocytopenia. Lancet 1991; 337: 1297-8.

73. Wyatt S, Joyner M, Daneshmend T. Filgrastim for mesalazine-associated neutropenia. Lancet 1993; 341: 1476
74. Gumaste V, Greenstein AJ, Meyers R, Sachar DB. Coombspositive autoimmune hemolytic anemia in ulcerative colitis. Dig Dis Sci 1989; 34: 1457-61.

75. Bell DW, Urban E, Sears DA, Walder AI, Ostrower VS. Ulcerative colitis complicated by autoimmune hemolytic anemia. S Med J 1981; 74: 359-61.

76. Altman AR, Maltz C, Janowitz HD. Autoimmune hemolytic anemia in ulcerative colitis: report of three cases, review of the literature, and evaluation of modes of therapy. Dig Dis Sci 1979; 24: 282-5.

77. Ma A, Datta M, Margosian E, Chen J, Horak I: T cells, but not $B$ cells, are required for bowel inflammation in interleukin 2-deficient mice. J Exp Med 1995; 182: 1567-72.

78. Ramakrishna R, Manoharan A. Auto-immune haemolytic anaemia in ulcerative colitis. Acta Haematol 1994; 91: 99 102.

79. Giannadaki E, Potamianos S, Roussomoustakaki M, Kyriakou D, Fragkiadakis N, Manousos ON. Autoimmune hemolytic anemia and positive Coombs test associated with ulcerative colitis. Am J Gastroenterol 1997; 92: 1872-4.

80. Teplitsky V, Virag I, Halabe A. Immune complex haemolytic anaemia associated with sulfasalazine. Br Med J 2000; 320 : 1113.

81. Mechanick JI. Coombs' positive hemolytic anemia following sulfasalazine therapy in ulcerative colitis: case reports, review, and discussion of pathogenesis. Mount Sinai J Med 1985; 52: 667-70.

82. van Hees PA, van Elferen $\mathrm{LW}$, van Rossum JM, van Tongeren JH. Hemolysis during salicylazosulfapyridine therapy. Am J Gastroenterol 1978; 70: 501-5.

83. Yates P, Macht LM, Williams NA, Elson CJ. Red cell autoantibody production by colonic mononuclear cells from a patient with ulcerative colitis and autoimmune haemolytic anaemia. Br J Haematol 1992; 82: 753-6.

84. Murphy PT, Cunney R, Nolan A, O'Donnell JR. Autoimmune haemolytic anaemia associated with ulcerative colitis. Irish Med J 1996; 89: 172-3.

85. Cohen SM, Rosenthal DS, Karp PJ. Ulcerative colitis and erythrocyte G6PD deficiency. Salicylazosulfapyridine-provoked hemolysis. J Am Med Assoc 1968; 205: 528-30.

86. Dahlback B, Blood coagulation. Lancet 2000; 355: 1627-32.

87. Aichbichler BW, Petritsch W, Reicht GA et al. Anti-cardiolipin antibodies in patients with inflammatory bowel dis. ease. Dig Dis Sci 1999; 44: 852-6.

88. Schapira M, Henrion J, Ravoet C et al.Thromboembolism in inflammatory bowel disease. Acta Gastroenterol Belg $1999 ; 62: 182-6$.

89. Talbot RW, Heppell J, Dozois RR, Beart RW, Jr. Vascular complications of inflammatory bowel disease. Mayo Clin Proc 1986; 61: 140-5.

90. Jackson LM, O'Gorman PJ, O'Connell J, Cronin CC, Cotter KP, Shanahan F. Thrombosis in inflammatory bowel disease: clinical setting, procoagulant profile and factor $\mathrm{V}$ Leiden. Q J Med 1997; 90: 183-8.

91. Koenigs KP, McPhedran P, Spiro HM. Thrombosis in inflammatory bowel disease. J Clin Gastroenterol 1987; 9: 627-31.

92. Johns DR. Cerebrovascular complications of inflammatory bowel disease. Am J Gastroenterol 1991; 86: 367-70.

93. Carmona MA, Jaume Anselmi F, Ramirez Rivera J. Cerebral thrombosis and vasculitis: an uncommon complication of ulcerative colitis. Bol Asoc Med Puerto Rico 2000; 92: 9 11.

94. Papi C, Ciaco A, Acierno G et al. Severe ulcerative colitis, dural sinus thrombosis, and the lupus anticoagulant. Am J Gastroenterol 1995; 90: 1514-7.

95. Musio F, Older SA, Jenkins T, Gregorie EM. Case report: cerebral venous thrombosis as a manifestation of acute ulcerative colitis. Am J Med Sci 1993; 305: 28-35. 
96. Markowitz RL, Ment LR, Gryboski JD. Cerebral thromboembolic disease in pediatric and adult inflammatory bowel disease: case report and review of the literature. J Pediatr Gastroenterol Nutr 1989; 8: 413-20.

97. Bansal R, Goel A. Ulcerative colitis with sagittal sinus thrombosis with normal coagulation profile. Ind J Gastroenterol 2000; 19: 88-9.

98. Derdeyn CP, Powers WJ. Isolated cortical venous thrombosis and ulcerative colitis. Am J Neuroradiol 1998; 19: 48890.

99. Crowe A, Taffinder N, Layer GT, Irvine A, Nicholls RJ. Portal vein thrombosis in a complicated case of Crohn's disease. Postgrad Med J 1992; 68: 291-3.

100. Miyazaki Y, Shinomura Y, Kitamura S et al. Portal vein thrombosis associated with active ulcerative colitis: percutaneous transhepatic recanalization. Am J Gastroenterol 1995; 90: $1533-4$.

101. Chesner IM, Muller S, Newman J. Ulcerative colitis complicated by Budd-Chiari syndrome. Gut 1986; 27: 1096 100.

102. Maccini DM, Berg JC, Bell GA. Budd-Chiari syndrome and Crohn's disease. An unreported association. Dig Dis Sci 1989; 34: 19336 .

103. Brinson RR, Curtis WD, Schuman BM, Mills LR. Recovery from hepatic vein thrombosis (Budd Chiari syndrome) complicating ulcerative colitis. Dig Dis Sci 1988; 33: 1615 20.

104. Praderio L, Dagna L, Longhi P, Rubin G, Sabbadini MG. Budd Chiari syndrome in a patient with ulcerative colitis: association with anticardiolipin antibodies. J Clin Gastroenterol 2000: 30: 2034.

105. Halliday CE, Farthing MJ. Arterial thrombosis in Crohn's discase. Med J Austr 1988; 149: 55960.

106. Kyrle PA. Minar E. Hirschl M et al. High plasma levels of factor VIII and the risk of recurrent venous thromboembolism. N Engl J Med 2000; 343: 45762.

107. Chiarantini E, Valanzano R, Liotta AA. Hemostatic abnormalities in inflammatory bowel disease. Thromb Res 1996: 82: 13746.

108. Smith CJ, Haire WD, Kaufman SS, Mack DR. Determination of prothrombin activation fragments in young patients with inflammatory bowel disease. Am J Gastroenterol 1996; 91: 1221-5.

109. Chamouard P, Grunebaum L, Wiesel ML et al. Prothrombin fragment $1+2$ and thrombin-antithrombin III complex as markers of activation of blood coagulation in inflammatory bowel diseases. Eur J Gastroenterol Hepatol 1995; 7: 1183 8.

110. Souto JC, Martinez E. Roca M et al.Prothrombotic state and signs of endothelial lesion in plasma of patients with inflammatory bowel disease. Dig Dis Sci 1995; 40: 1883-9.

111. Koutroubakis IE, Sfiridaki A, Mouzas IA et al. Resistance to activated protein $C$ and low levels of free protein $S$ in Greek patients with inflammatory bowel disease. Am $J$ Gastroenterol 2000; 95: 190-4.

112. Lee LC, Spittell JA, Jr, Sauer WG, Owen CA, Jr, Thompson $\mathrm{JH}, \mathrm{Jr}$. Hypercoagulability associated with chronic ulcerative colitis: changes in blood coagulation factors. Gastroenterology 1968; 54: 76-85.

113. Braverman D, Bogoch A. Arterial thrombosis in ulcerative colitis. Am J Dig Dis 1978; 23: 1148-50.

114. Aadland E, Odegaard OR, Roseth A, Try K. Free protein S deficiency in patients with Crohn's disease. Scand J Gastroenterol 1994; 29 : 333-5.

115. Talstad I, Rootwelt K, Gjone E. Thrombocytosis in ulcerative colitis and Crohn's disease. Scand J Gastroenterol 1973; 8: 135-8.

116. Lam A, Borda I, Inwood M, Thomson S. Coagulation studies in ulcerative colitis and Crohn's disease. Gastroenterology 1975; 68: 245-51.
117. Morowitz D, Allen L, Kirsner J. Thrombocytosis in chronic inflammatory bowel disease. Ann Intern Med 1968; 68: 1013-21.

118. Vecchi M, Cattaneo M, de Franchis R, Mannucci PM. Risk of thromboembolic complications in patients with inflammatory bowel disease. Study of hemostasis measurements. Int J Clin Lab Res 1991; 21: 165-70.

119. Heneghan MA, Cleary B, Murray M, O'Gorman TA, McCarthy CF. Activated protein $\mathrm{C}$ resistance, thrombophilia, and inflammatory bowel disease. Dig Dis Sci 1998; 43: $1356-61$.

120. Webberley MJ, Hart MT, Melikian V. Thromboembolism in inflammatory bowel disease: role of platelets, Gut 1993; 34 : 247-51.

121. Chiarantini E, Valanzano R, Liotta AA et al. Persistence of hemostatic alterations in patients affected by Crohn's disease after bowel surgery. Thromb Res 1997: 87: 539 46.

122. Heits F. Stahl M, Ludwig D, Stange EF, Jelkmann W. Elevated serum thrombopoietin and interleukin-6 concentrations in thrombocytosis associated with inflammatory bowel disease. J Interferon Cytokine Res 1999: 19: 75760 .

123. Sands BE, Bank S, Sninsky CA et al. Preliminary evaluation of safety and activity of recombinant human interleukin 11 in patients with active Crohn's disease. Gastroenterology 1999: 117: 5864.

124. Hudson M. Chitolie A. Hutton RA. Smith MS. Pounder RE, Wakefield AJ. Thrombotic vascular risk factors in inflammatory bowel disease. Gut 1996; 38: 7337.

125. Chamouard P. Grunebaum L, Wiesel ML " $a$ l. Prevalence and significance of anticardiolipin antibodies in Crohn's discase. Dig Dis Sci 1994: 39: 15014.

126. Koutroubakis IE, Petinaki E, Anagnostopoulou E et al. Anti-cardiolipin and anti-beta2-glycoprotein I antibodies in patients with inflammatory bowel diseasc. Dig Dis Sci 1998; 43: $2507 \quad 12$.

127. Vianna JL, D'Cruz DP, Khamashta MA, Asherson RA, Hughes GR. Anticardiolipin antibodies in a patient with Crohn's disease and thrombosis. Clin Exp Rheumatol 1992; 10: 1658 .

128. Olds RJ, Fitches AC, Geary CP. The multigenic basis for venous thrombosis. Br J Haematol 2000; 109: 508-11.

129. Dahlback B. New molecular insights into the genetics of thrombophilia. Resistance to activated protein $C$ caused by Arg (506) to Gln mutation in Factor $V$ as a pathogenic risk factor for venous thrombosis. Thromb Haemostas 1995; 74: $139-48$.

130. Sheppard DR. Activated protein $C$ resistance: the most common risk factor for venous thromboembolism. J Am Board Fam Pract 2000; 13: 111-5.

131. De Stefano V, Martinelli I, Mannucci PM, Paciaroni K, Chiusolo P, Casorelli I, Rossi E, Leone G. The risk of recurrent deep venous thrombosis among heterozygous carriers of both factor $\mathrm{V}$ Leiden and the G20210A prothrombin mutation. N Engl J Med 1999; 341: 801-6.

132. Vecchi M, Sacchi E, Saibeni S et al. Inflammatory bowel diseases are not associated with major hereditary conditions predisposing to thrombosis. Dig Dis Sci 2000; 45: 1465-9.

133. Zauber NP, Sabbath-Solitare M, Rajoria G, Mogan G Factor $\mathrm{V}$ Leiden mutation is not increased in patients with inflammatory bowel disease. J Clin Gastroenterol 1998; 27 215-6.

134. Levine A, Lahav J, Zahavi I, Raz A, Dinari G. Activated protein $C$ resistance in pediatric inflammatory bowel disease. J Pediatr Gastroenterol Nutr 1998; 26: 172-4.

135. Haslam N, Standen GR, Probert CS. An investigation of the association of the factor $\mathrm{V}$ Leiden mutation and inflammatory bowel disease. Eur J Gastroenterol Hepatol 1999; 11 : 1289-91. 
136. Over HH, Ulgen S, Tuglular $\mathrm{T}$ et al. Thrombophilia and inflammatory bowel disease: does factor $\mathrm{V}$ mutation have a role? Eur J Gastroenterol Hepatol 1998; 10: 827-9.

137. Novacek G, Michsler W, Kapiotis S, Katzenschlager R, Speiser W, Vogelsang $H$. Thromboembolism and resistance to activated protein $\mathrm{C}$ in patients with inflammatory bowel disease. Am J Gastroenterol 1999; 94: 685-90.

138. Liebman HA, Kashani N, Sutherland D, McGehee W, Kam $A L$. The factor $V$ Leiden mutation increases the risk of venous thrombosis in patients with inflammatory bowel disease. Gastroenterology 1998; 115: 830 4 .

139. Cattaneo M, Vecchi M, Zighetti ML, et al. High prevalence of hyperchomocysteinemia in patients with inflammatory bowel disease: a pathogenic link with thromboembolic complications? Thromb Haemostas $1998 ; 80$ : 542-5.

140. Mahmud N, Molloy A, McPartlin J et al. Increased prevalence of methylenetetrahydrofolate reductase $\mathrm{C} 677 \mathrm{~T}$ variant in patients with inflammatory bowel disease, and its clinical implications. Gut 1999; 45: 389-94.

141. Oldenburg B, Fijnheer R, van der Griend R, vanBergeHenegouwen GP, Koningsberger JC. Homocysteine in inflammatory bowel disease: a risk factor for thromboembolic complications? Am J Gastroenterol 2000; 95: 2825-30.

142. Thompson N, Wakefield A, Pounder R. Inherited disorders of coagulation appear to protect against inflammatory bowel disease. Gastroenterology 1995; 108: 1011-15.

143. Kearon C, Gent M, Hirsh J et al. A comparison of three months of anticoagulation with extended anticoagulation for a first episode of idiopathic venous thromboembolism [published erratum appears in N Engl J Med 1999 22; 341: 298]. N Engl J Med 1999; 340: 901-7.

144. Gaffney PR, Doyle CT, Gaffney A, Hogan J, Hayes DP, Annis $P$. Paradoxical response to heparin in 10 patients with ulcerative colitis. Am J Gastroenterol 1995; 90: 220-3.

145. Van Woert JH, Thompson RC, Cangemi JR, Metzger PP, Blackshear JL, Fleming CR. Streptokinase therapy for extensive venous thromboses in a patient with severe ulcerative colitis. Mayo Clin Proc 1990; 65: 1144-9.

146. Kermode AG, Ives FJ, Taylor B, Davis SJ, Carroll WM. Progressive dural venous sinus thrombosis treated with local streptokinase infusion [Letter]. J Neurol Neurosurg Psychiatry 1995; 58 : 107-8.

147. Nguyen A. Prothrombin G20210A polymorphism and thrombophilia. Mayo Clin Proc 2000; 75: 595-604

148. Muller S, Chesner IM, Sheridan J, Newman J. Ulcerative colitis complicated by disseminated intravascular coagulation. Postgrad Med J 1987; 63: 689-91.

149. Ryan FP, Timperley WR, Preston FE, Holdsworth CD. Cerebral involvement with disseminated intravascular coagulation in intestinal disease. J Clin Pathol 1977; 30: 551-5.

150. Wong TZ, Welch JP, Holt JB. Intraoperative disseminated intravascular coagulation in a patient with ulcerative colitis. Connect Med 1989; 53: 577-8.

151. Zlatanic J, Korelitz BI, Wisch $\mathrm{N}$ et al. Inflammatory bowel disease and immune thrombocytopenic purpura: is there a correlation? Am J Gastroenterol 1997; 92: 2285-8.

152. Mones RL. Thrombocytopenia and hypofibrinogenemia in association with inflammatory bowel disease. J Pediatr Gastroenterol Nutr 1983; 2: 175-7.

153. Gremse DA, Bancroft J, Moyer MS. Sulfasalazine hypersensitivity with hepatotoxicity, thrombocytopenia, and erythroid hypoplasia. J Pediatr Gastroenterol Nutr 1989; 9: $261-3$

154. Caprilli R, Corrao G, Taddei G, Tonelli F, Torchio P, Viscido A. Prognostic factors for postoperative recurrence of Crohn's disease. Gruppo Italiano per lo Studio del Colon e del Retto (GISC). Dis Colon Rectum 1996; 39: 335-41.

155. Loftus EV, Jr., Tremaine WJ, Habermann TM, Harmsen WS, Zinsmeister AR, Sandborn WJ. Risk of lymphoma in inflammatory bowel disease. Am J Gastroenterol 2000; 95 : $2308-12$.

156. Connell WR, Kamm MA, Dickson M, Balkwill AM, Ritchie JK, Lennard-Jones JE. Long-term neoplasia risk after azathioprine treatment in inflammatory bowel disease. Lancet $1994 ; 343$ : 1249-52.

157. Caspi O, Polliack A, Klar R, Ben-Yehuda D. The association of inflammatory bowel disease and leukemia - coincidence or not? Leukemia Lymphoma 1995; 17: 255-62.

158. Georgescu L, Quinn GC, Schwartzman S, Paget SA. Lymphoma in patients with rheumatoid arthritis: association with the disease state or methotrexate treatment. Semin Arthritis Rheum 1997; 26: 794-804.

159. Greenstein AJ, Mullin GE, Strauchen JA et al. Lymphoma in inflammatory bowel disease. Cancer 1992; 69: 1119-23.

160. Palli D, Trallori G, Bagnoli S et al. Hodgkin's disease risk is increased in patients with ulcerative colitis. Gastroenterology 2000; 119: 647-53.

161. Korelitz BI, Mirsky FJ, Fleisher MR, Warman JI, Wisch N, Gleim GW. Malignant neoplasms subsequent to treatment of inflammatory bowel disease with 6-mercaptopurine. Am J Gastroenterol 1999; 94: 3248-53.

162. Present DH, Korelitz BI, Wisch N, Glass JL, Sachar DB, Pasternack BS. Treatment of Crohn's disease with 6-mercaptopurine. A long-term, randomized, double-blind study. N Engl J Med 1980; 302: 981-7.

163. Present DH, Meltzer SJ, Krumholz MP, Wolke A, Korelitz BI. 6-Mercaptopurine in the management of inflammatory bowel disease: short- and long-term toxicity. Ann Intern Med 1989; 111: 641-9.

164. Schabet M. Epidemiology of primary CNS lymphoma. J Neuro-Oncol 1999; 43: 199-201.

165. Lewis JD, Schwartz JS, Lichtenstein GR. Azathioprine for maintenance of remission in Crohn's disease: benefits outweigh the risk of lymphoma. Gastroenterology $2000 ; 118$ $1018-24$

166. Bo J, Schroder H, Kristinsson J et al. Possible carcinogenic effect of 6-mercaptopurine on bone marrow stem cells relation to thiopurine metabolism. Cancer 1999; 86: 1080-6.

167. Kwong YL, Au WY, Liang RH. Acute myeloid leukemia after azathioprine treatment for autoimmune diseases: association with $-7 / 7 \mathrm{q}$. Cancer Genet Cytogenet 1998; 104: 947.

168. Heizer WD, Peterson JL. Acute myeloblastic leukemia following prolonged treatment of Crohn's disease with 6mercaptopurine. Dig Dis Sci 1998; 43: 1791-3.

169. DeMario MD, Liebowitz DN. Lymphomas in the immunocompromised patient. Semin Oncol 1998; 25: 492-502.

170. Nalesnik MA. Clinicopathologic features of posttransplant lymphoproliferative disorders. Ann Transplant 1997; 2: 3340.

171. Kumar S, Fend F, Quintanilla-Martinez L et al.Epstein-Barr virus-positive primary gastrointestinal Hodgkin's disease: association with inflammatory bowel disease and immunosuppression. Am J Surg Pathol 2000; 24: 66-73.

172. Calaminici MR, Sheaff MT, Norton AJ, Feakins RM. Ileocaecal Epstein-Barr virus-positive lymphoproliferative disorder complicating Crohn's disease [Letter]. Histopathology $1999 ; 35: 388-90$.

173. Larvol L, Soule JC, Le Tourneau A. Reversible lymphoma in the setting of azathioprine therapy for Crohn's disease [Letter]. N Engl J Med 1994; 331: 883-4.

174. Bickston SJ, Lichtenstein GR, Arseneau KO, Cohen RB, Cominelli $F$. The relationship between infliximab treatment and lymphoma in Crohn's disease. Gastroenterology 1999; 117: 1433-7.

175. Pardi DS, Tremaine WJ, Sandborn WJ, McCarthy JT. Renal and urologic complications of inflammatory bowel disease. Am J Gastroenterol 1998; 93: 504-14. 
176. Kahn E, Markowitz J, Simpser E, Aiges H, Daum F. Amyloidosis in children with inflammatory bowel disease. $\mathrm{J}$ Pediatr Gastroenterol Nutr 1989; 8: 447-53.

177. Lowdell CP. Shousha S, Parkins RA. The incidence of amyloidosis complicating inflammatory bowel disease. A prospective survey of 177 patients. Dis Colon Rectum 1986; 29: 351-4.

178. Falk RH, Comenzo RL, Skinner M. The systemic amyloidoses. N Engl J Med 1997; 337: 898-909.

179. Gillmore JD, Hawkins PN, Pepys MB. Amyloidosis. A review of recent diagnostic and therapeutic developments. Br J Haematol 1997; 99: 245-56.

180. Lovat LB, Madhoo S, Pepys MB, Hawkins PN. Long-term survival in systemic amyloid $A$ amyloidosis complicating Crohn's disease. Gastroenterology 1997; 112: 1362 5.

181. Edwards P, Cooper DA, Turner J, O'Connor TJ, Byrnes DJ. Resolution of amyloidosis (AA type) complicating chronic ulcerative colitis. Gastroenterology 1988; 95: 810-15.

182. Gertz MA, Kyle RA. Secondary systemic amyloidosis: response and survival in 64 patients. Medicine 1991; 70: 24656.

183. Fausa O. Nygaard K. Elgjo K. Amyloidosis and Crohn's discase. Scand J Gastroenterol 1977: 12:657 62

184. Meyers S, Janowitz HD, Gumaste VV at al. Colchicine therapy of the renal amyloidosis of ulcerative colitis. Gastroenterology 1988: 94: 15037 .
185. Menges M, Steffen HM. Secondary amyloidosis in ulcerative colitis - successful treatment with colchicine. $Z$ Gastroenterol 1996; 34: 753-6.

186. Gertz MA, Kyle RA. Amyloidosis: prognosis and treatment. Semin Arthritis Rheum 1994; 24: 124-38.

187. Ravid M, Shapira J, Kedar I, Feigl D. Regression of amyloidosis secondary to granulomatous ileitis following surgical resection and colchicine administration. Acta Hepato-Gastroenterol 1979; 26: 513-5.

188. Larvol L, Cervoni J, Besnier M, Dupouet L, Beaufils H, Clauvel J, Levecq $\mathrm{H}$. Reversible nephrotic syndrome in Crohn's disease complicated with renal amyloidosis. Gastroenterol Clin Biol 1998; 22: 639-41.

189. Horie Y, Chiba M, Miura K et al. Crohn's disease associated with renal amyloidosis successfully treated with an elemental diet. J Gastroenterol 1997; 32: 663-7.

190. Mandelstam P, Simmons DE, Mitchell B. Regression of amyloid in Crohn's disease after bowel resection. A 19-year follow-up. J Clin Gastroenterol 1989; 11: 3246.

191. Iwakiri R, Sakemi T, Fujimoto K. Dimethylsulfoxide for renal dysfunction caused by systemic amyloidosis complicating Crohn's disease [Letter; comment]. Gastroenterology 1999; 117: 1031 2 . 